\title{
LEFT VENTRICULAR PREPONDERANCE AND LEFT AXIS DEVIATION IN CYANOTIC CONGENITAL HEART DISEASE
}

BY

\author{
REDA M. SHAHER \\ From The Cardiac Department, Guy's Hospital, London
}

Received May 6, 1963

In 1936 Taussig said that, to the best of her knowledge, among patients with cyanotic heart disease, the only malformation that was associated with left axis deviation in the electrocardiogram was a diminutive or absent right ventricle. She reported one case of tricuspid atresia and another of pulmonary atresia with a closed ventricular septum, in each of which the cardiogram showed left axis deviation. Cleland et al. (1957) thought that the association of central cyanosis with left axis deviation was virtually pathognomonic of tricuspid atresia. Astley, Oldham, and Parsons (1953) and Scott (1955) agreed with others that left ventricular preponderance or much left axis deviation in cyanotic heart disease was almost always diagnostic of tricuspid atresia with a rudimentary right ventricle. There are, however, many exceptions.

Wood (1942) reported a case of pulmonary stenosis with a closed ventricular septum and an atrial septal defect associated with central cyanosis: there was left axis deviation and at necropsy the left ventricle was found to be enlarged. Gasul, Richmond, and Krakower (1949) reported a case of Fallot's tetralogy with a patent foramen ovale which was also associated with left ventricular hypertrophy and left axis deviation. Portillo et al. (1959) reported a case that was diagnosed as tricuspid atresia because of the combination of severe central cyanosis and left axis deviation; but at necropsy the patient was found to have Fallot's tetralogy. Soloff (1949) reported a cyanosed baby who died at the age of 2 weeks: there was left axis deviation and at necropsy there was aortic atresia associated with hypoplasia of the left ventricle and gross enlargement of the right ventricle. Uhl (1952) reported another case of a cyanosed baby who died at the age of 7 months, whose cardiogram on one occasion suggested left ventricular hypertrophy: at necropsy almost complete absence of the myocardium of the right ventricle was found, but no intracardiac defect was found to account for the central cyanosis.

More recently, however, patients with conditions other than tricuspid atresia, who had central cyanosis and cardiograms with left axis deviation, left ventricular preponderance, or both, have been reported. Neill and Brink (1955) and Shaher (1963) have shown that the cardiogram in single ventricle often shows a pattern of left ventricular dominance as well as left axis deviation. Pung, Gottstein, and Hirsch (1955) noted that left ventricular preponderance had been present throughout the life of a deeply cyanosed boy who died at the age of 18 years and who proved at autopsy to have transposition of the great vessels with a closed ventricular septum and pulmonary infundibular stenosis. Keith, Rowe, and Vlad (1958) found that left ventricular dominance in cases of transposition of the great vessels indicated tricuspid atresia or an overriding tricuspid valve.

In a recent review of complete transposition of the great vessels, Noonan et al. (1960) have added transposition with a ventricular septal defect and a large pulmonary blood flow to the list of conditions associated with left ventricular dominance. Becu et al. (1955) reported a case that was diagnosed on clinical and hæmodynamic grounds as tricuspid atresia, but at operation, corrected transposition of the great vessels was found. Several cases of hypoplasia of the right ventricle that were not associated with valvar defects have been reported in recent years (Cooley et al., 1950; Gasul et al., 1959; Medd et al., 1961; and Sackner et al., 1961). These authors have shown that the combination of central cyanosis, left ventricular preponderance, and left axis deviation is often a feature of this syndrome. 
There are recent descriptions of two cases of isolated anomalous drainage of the superior vena cava (Wood, 1956; and Tuchman et al., 1956) and two cases of isolated anomalous drainage of the inferior vena cava (Gardner and Cole, 1955; and Meadows, Bergstrand, and Sharp, 1961) into the left atria: it seems that central cyanosis and left ventricular preponderance are among the features of this syndrome. Davignon et al. (1961) have shown that the condition of pulmonary atresia with a closed ventricular septum and a normal tricuspid valve is usually associated with left ventricular preponderance and right axis deviation. Neufeld et al. $(1961,1962)$ have shown that in the syndrome of origin of both great vessels from the right ventricle without pulmonary stenosis and with an infracristal ventricular septal defect the combination of central cyanosis and left axis deviation may be present: they have also shown that evidence of right or combined ventricular hypertrophy is usually present.

Astley et al. (1953) saw the combination of central cyanosis and left axis deviation in Eisenmenger's complex, complete transposition of the great vessels, single ventricle with persistent truncus arteriosus, and in a child whose cyanosis was due to methæmoglobinæmia. Cleland et al. (1957) found that the combination of right ventricular hypertrophy and left axis deviation may occur in Eisenmenger's "disease" and truncus arteriosus as well as in single ventricle. Brink and Neill (1955) found that in cyanotic patients, left axis deviation was overwhelmingly associated with tricuspid atresia, although they saw it in single ventricle, and Eisenmenger's complex: in their series, left axis deviation was not present in Fallot's tetralogy, pulmonary stenosis, or transposition of the great vessels. Gasul et al. (1950) reported two patients who were cyanosed only during the first six months of life and whose cardiograms showed left axis deviation: they believed that both of these patients had Ebstein's disease with a patent foramen ovale.

The object of this paper is to discuss, from the material in two cardiac centres, the relative incidence of the various cyanotic cardiac malformations that may give rise to left axis deviation, left ventricular preponderance, or the combination of both in the cardiogram.

\section{SUBJECTS}

The cases reported in this paper were collected from Guy's Hospital and Southampton Chest Hospital: 65 patients with cyanotic heart disease whose electrocardiograms showed left axis deviation, left ventricular preponderance, or the combination of both features were selected. Left axis deviation was considered present in children below the age of 10 years if the mean projection of the $\mathrm{QRS}$ vector ranged from +60 degrees to -90 degrees, and in patients over the age of 10 years if the electrical axis ranged from 0 degrees to -90 degrees. In interpreting the præcordial leads, the term preponderance is used to indicate the dominance of one ventricle over the other. In this sense left ventricular preponderance is normal in healthy adults. Left ventricular preponderance was considered to be present in children or in adults if the normal adult pattern of left ventricular preponderance was found in the præcordial leads, i.e. dominant $\mathrm{R}$ waves in V6 and dominant $\mathrm{S}$ waves in V1. Of 57 patients, diagnosis was established by necropsy in 23 , by operation in 6 , by cardiac catheterization in 4 , and by angiography in 24 . Of the remaining 8 patients who had not been finally diagnosed, 3 were thought to be probable cases of tricuspid atresia, and in the other 5 this diagnosis was thought to be unlikely. Of the total series of 65 patients (Table I), 8 were seen at Southampton Chest Hospital and 57 at Guy's Hospital. Fifty patients had left axis deviation (Table II), 43 patients had left ventricular preponderance (Table II), and 28 patients had both left axis deviation and left ventricular preponderance (Table I). There were 36 male and 29 female patients. The ages ranged from a few weeks to 40 years (Tables I and II).

\section{RESULTS}

In the whole group of 65 patients with left axis deviation, left ventricular preponderance or the combination of both (Table I), transposition of the great vessels was present in 16, single ventricle in 14, and tricuspid atresia in 13 . In the 50 patients with left axis deviation (Table II), tricuspid atresia accounted for 13, single ventricle for 11, and transposition of the great vessels for 8 . In the 43 with left ventricular preponderance (Table II), tricuspid atresia accounted for 11, transposition of the great vessels for 11, and single ventricle for 9 patients. In the 28 with both left 
TABLE I

Age and Diagnosis of 65 Patients with Left Axis Deviation, Left Ventricular Preponderance, or Both, WITH THE LAST SHOWN SEPARATELY ON THE RIGHT

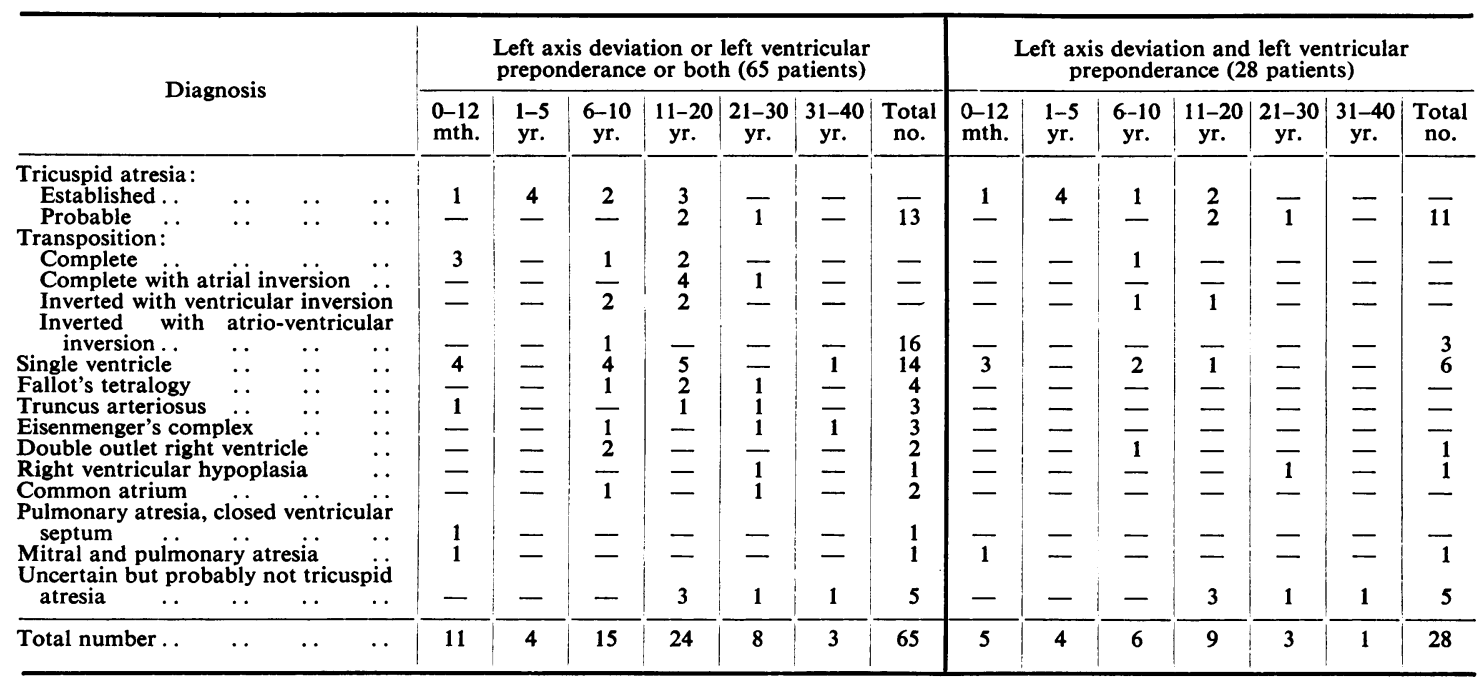

TABLE II

Age and Diagnosis of 50 Patients with Left Axis Deviation and of 43 Patients with Left Ventricular PREPONDERANCE

\begin{tabular}{|c|c|c|c|c|c|c|c|c|c|c|c|c|c|c|}
\hline \multirow{2}{*}{ Diagnosis } & \multicolumn{7}{|c|}{ Left axis deviation ( 50 patients) } & \multicolumn{7}{|c|}{ Left ventricular preponderance (43 patients) } \\
\hline & $\begin{array}{l}0-12 \\
\text { mth. }\end{array}$ & $\begin{array}{l}1-5 \\
\text { yr. }\end{array}$ & $\begin{array}{l}6-10 \\
\text { yr. }\end{array}$ & \begin{tabular}{|c|}
$11-20$ \\
$\mathrm{yr}$.
\end{tabular} & $\begin{array}{c}21-30 \\
\mathrm{yr} .\end{array} \mid$ & \begin{tabular}{|c|}
$31-40$ \\
$\mathrm{yr}$.
\end{tabular} \mid & $\begin{array}{c}\text { Total } \\
\text { no. }\end{array}$ & $\begin{array}{l}0-12 \\
\text { mth. }\end{array}$ & $\begin{array}{l}1-5 \\
\text { yr. }\end{array}$ & $\begin{array}{l}6-10 \\
\text { yr. }\end{array}$ & $\begin{array}{c}11-20 \\
\mathrm{yr} .\end{array}$ & $\begin{array}{c}21-30 \\
\text { yr. }\end{array}$ & $\begin{array}{c}31-40 \\
\mathrm{yr} .\end{array}$ & $\begin{array}{c}\text { Total } \\
\text { no. }\end{array}$ \\
\hline $\begin{array}{l}\text { Tricuspid atresia : } \\
\text { Established } .: \\
\text { Probable } . .\end{array}$ & 1 & $\frac{4}{-}$ & $\underline{2}$ & $\begin{array}{l}3 \\
2\end{array}$ & 1 & - & 13 & $\underline{1}$ & 4 & 1 & 2 & 1 & 二 & 11 \\
\hline $\begin{array}{c}\text { Probable } \\
\text { Transposition: } \\
\text { Complete }\end{array}$ & - & - & 1 & 2 & 1 & - & 13 & - & - & $\overline{2}$ & 2 & 1 & - & 11 \\
\hline $\begin{array}{l}\text { Complete with atriai inversion } \\
\text { Inverted with ventricular inversion } \\
\text { Inverted with atrio-ventricular }\end{array}$ & 二 & $=$ & $\frac{1}{1}$ & $\begin{array}{l}2 \\
1\end{array}$ & 1 & $\bar{z}$ & $=$ & $\bar{z}$ & 二 & $\frac{2}{2}$ & $\frac{2}{2}$ & $\bar{z}$ & $\bar{z}$ & $\bar{z}$ \\
\hline 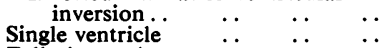 & 3 & $\overline{-}$ & $\frac{1}{2}$ & 5 & $\bar{z} \cdot r \cdot r \cdot r \cdot r \cdot r \cdot r \cdot r$ & $\overline{1}$ & ${ }_{11}^{8}$ & 4 & 二 & 4 & 1 & 二 & $\overline{-}$ & ${ }_{9}^{11}$ \\
\hline gy $\quad .$. & - & - & - & 2 & 1 & - & 3 & - & 二 & 1 & $\frac{1}{1}$ & 二 & 二 & 1 \\
\hline $\begin{array}{ll}\text { Truncus arteriosus } \\
\text { Eisenmenger's complex }\end{array}$ & 二 & 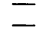 & $\overline{1}$ & 二 & 1 & $\overline{1}$ & $\frac{1}{3}$ & 1 & 二 & 二 & 1 & 二 & $=$ & 2 \\
\hline Double outlet right ventr & - & - & 2 & - & 1 & - & 2 & 二 & 二 & $\overline{1}$ & 二 & $\overline{-}$ & 二 & 1 \\
\hline $\begin{array}{l}\text { Right ventricular hypoplasia } \\
\text { Common atrium }\end{array}$ & - & 二 & $\overline{1}$ & 二 & $\begin{array}{l}1 \\
1\end{array}$ & 二 & $\frac{1}{2}$ & 二 & 二 & 二 & 二 & 1 & $\bar{z}$ & 1 \\
\hline $\begin{array}{l}\text { Pulmonary atresia, closed ventricular } \\
\text { septum }\end{array}$ & & - & - & & & & & 1 & - & - & - & - & - & 1 \\
\hline Mitral and pulmonary atresia $\ddot{.0}$ & 1 & - & - & - & - & - & 1 & 1 & - & - & - & - & - & 1 \\
\hline atresia & - & - & - & 3 & 1 & 1 & 5 & - & - & - & 3 & 1 & 1 & 5 \\
\hline Total number. & 5 & 4 & 11 & 19 & 8 & 3 & 50 & 11 & 4 & 11 & 13 & 3 & 1 & 43 \\
\hline
\end{tabular}

ventricular preponderance and left axis deviation (Table I), tricuspid atresia accounted for 11, single ventricle for 6 , and transposition of the great vessels for 3 patients. Following the three syndromes just mentioned, Fallot's tetralogy, truncus arteriosus, and Eisenmenger's complex are the three most common causes of left axis deviation or left ventricular preponderance in the cardiogram. None of these last three, however, has shown the combination of both left axis deviation and left ventricular preponderance. Not one of our 57 patients in whom a diagnosis was established, had isolated drainage of the superior or inferior vena cava into the left atrium, pulmonary stenosis with a closed ventricular septum and shunt reversal at atrial level, or Ebstein's disease. 
TABLE III

Incidence of Left Axis Deviation or Left Ventricular Preponderance or Both in the Diagnostic Categories StUdied



Table III indicates the incidence of left axis deviation, left ventricular preponderance, or both in the diagnostic categories studied.

\section{DISCUSSION}

Our figures and recent reports that have already been referred to suggest that the earlier statement of Astley et al. (1953) and Scott (1955), that left axis deviation or left ventricular preponderance in the cardiogram of a cyanosed patient is almost diagnostic of tricuspid atresia, is exaggerated. It seems that left axis deviation or left ventricular preponderance in the cardiogram is neither diagnostic nor pathognomonic of tricuspid atresia. In the whole group of 65 patients, tricuspid atresia only accounted for 20 per cent; in the group of 50 with left axis deviation it accounted for 26 per cent; in the group of 43 with left ventricular preponderance it accounted for 25.5 per cent; while in the group of 28 with left axis deviation and left ventricular preponderance it accounted for 40 per cent. It appears that the three most common causes of left ventricular preponderance or left axis deviation in the cardiogram of a cyanosed patient are tricuspid atresia, transposition of the great vessels, and single ventricle. Their order of frequency obviously depends on whether left ventricular preponderance, left axis deviation, or both are used for assessment. If combined left ventricular preponderance and left axis deviation is used in assessment, tricuspid atresia will be the most common single cause and will account for nearly half. Other types of cyanotic heart disease, although they may be individually rare, collectively exceed the number of cases of tricuspid atresia giving rise to this cardiographic pattern. Our figures suggest that a diagnosis of tricuspid atresia based only on the evidence of left axis deviation or left ventricular preponderance is likely to be correct in only 20-40 per cent of cyanotic patients. This percentage is likely to be slightly higher in the younger age-groups, and slightly lower in the older age-groups. The number of patients and their relative incidence in the different age-groups is shown in the Tables. In this context, we must point out that the occurrence of cases of tricuspid atresia with right axis deviation and right ventricular preponderance tends to diminish even further the chances of a correct diagnosis of tricuspid atresia on electrocardiographic evidence alone. Three of our patients (not in this series) with tricuspid atresia that was proved at necropsy showed right axis deviation, two (J.B. and C.L.) with the præcordial pattern of right ventricular preponderance (Fig. 1), and the third (M.T.) with only deep S waves from V1-6 (Fig. 2). A fourth patient (D.P.) also with tricuspid atresia proved at necropsy, had left axis deviation together with the præcordial pattern of right ventricular preponderance and $T$ wave inversion in leads V1-3 (Fig. 3). The occurrence of cases 


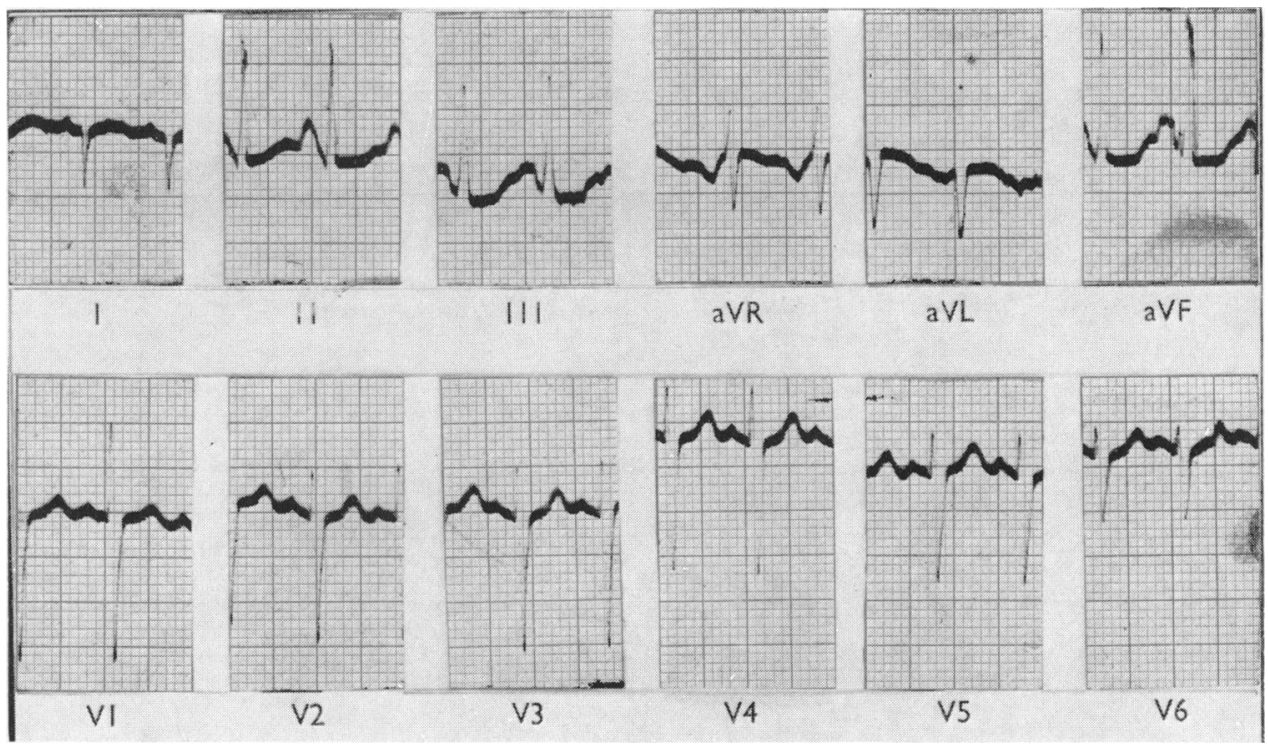

Fig. 1.-Cardiogram of patient J.B. (8 years), showing right axis deviation and right ventricular preponderance. Chest lead sensitivity, $1 \mathrm{mv}=0.5 \mathrm{~cm}$.

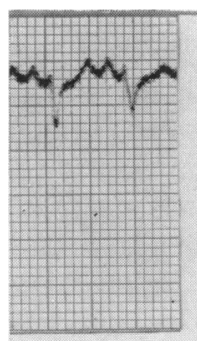

।

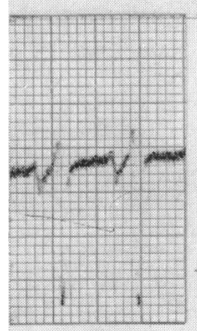

VI



11

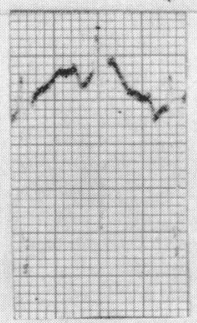

$\mathrm{V} 2$



111

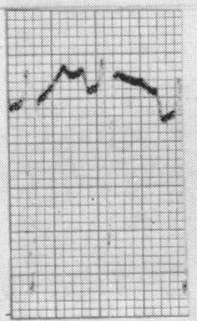

V3

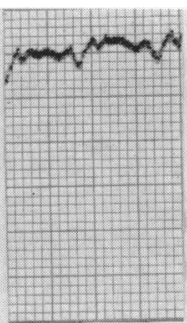

$\mathrm{aVR}$

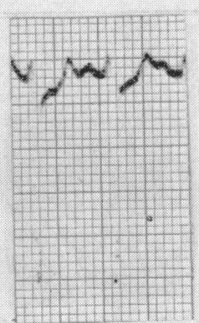

V4

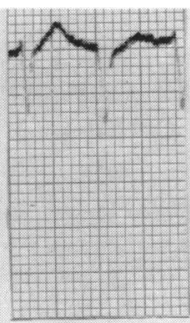

aVL

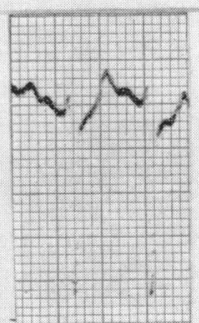

V5

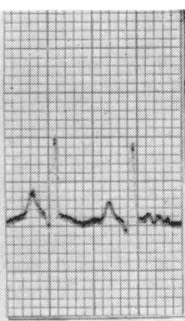

aVF

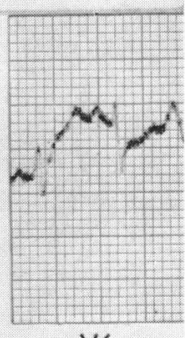

V6

FIG. 2.-Cardiogram of patient M.T. (3 months), showing right axis deviation and deep $\mathrm{S}$ waves from V1 to $V 6$. 


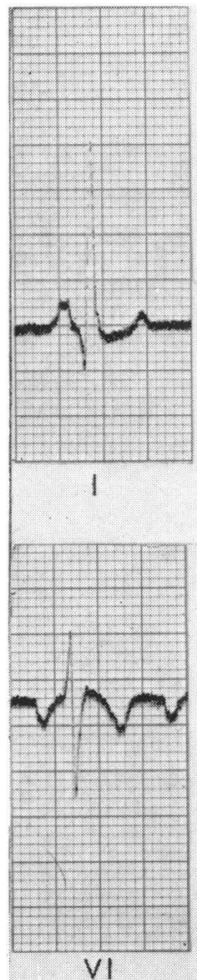

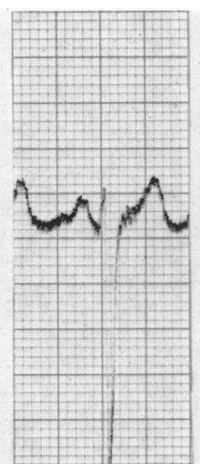

11

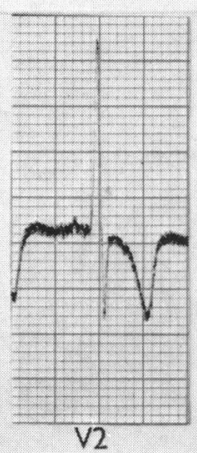

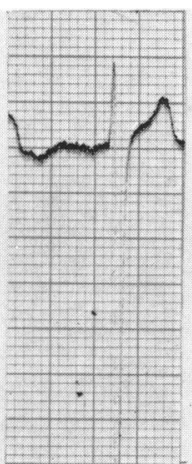

111

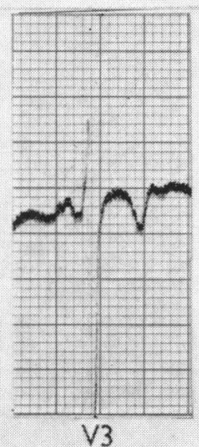

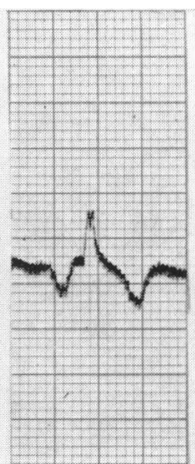

aVR

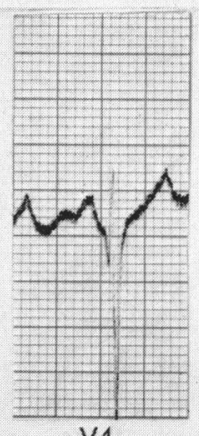

V4



aVL

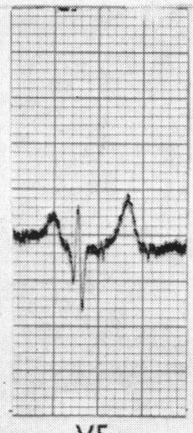

V5

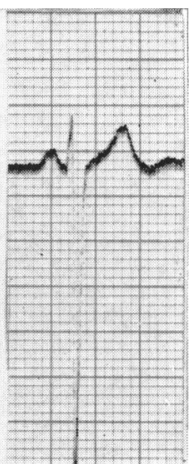

aVF

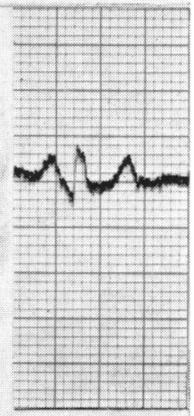

V6

FIG. 3.-Cardiogram of patient D.P. (8 years) showing left axis deviation and the præcordial pattern of right ventricular preponderance with inversion of the $T$ waves from $V 1$ to $V 3$.

of tricuspid atresia with right axis deviation or right ventricular preponderance, is moreover recognized (Kroop and Grishman, 1950; Nadas, 1957; Sullivan and Mangiardi, 1958; and Somlyo and Halloran, 1962).

Seventeen patients studied in this paper were originally diagnosed on cardiographic evidence, as having tricuspid atresia; but cardiac investigation, operation, or necropsy established a diagnosis of single ventricle in 6 , corrected transposition (inverted transposition with ventricular inversion) in 2, complete transposition in 1, Fallot's tetralogy in 2, common atrium in 1, hypoplasia of the right ventricle in 1 , double outlet right ventricle with pulmonary stenosis in 2 , and combined mitral and pulmonary atresia in 1 . In the remaining patient no final diagnosis was established, but cardiac catheterization demonstrated a large left-to-right shunt at atrial level.

Case history. A boy of 7 years (P.M.), who was seen at Southampton Chest Hospital, had been breathless and cyanosed since birth. His cardiogram (Fig. 4) showed left axis deviation and left ventricular preponderance. Cardiac catheterization and selective angiocardiography were both performed twice, and the results of these studies were thought to establish the diagnosis of tricuspid atresia with transposition of the great vessels. Angiocardiography with a selective right atrial injection showed a straight edge overlying the vertebral column (Fig. 5), which was thought to be caused by the atresic tricuspid valve. At open heart surgery the presence of complete transposition of the great vessels was confirmed, but the tricuspid valve was found to be normal.

Ingomar and Terslev (1962), reporting on patients who had been clinically diagnosed as having tricuspid atresia, found later that this diagnosis was accurate in only 6 of 16 patients. In a previous paper from this department, Campbell (1961) reported on 40 cases under the title of tricuspid atresia, 

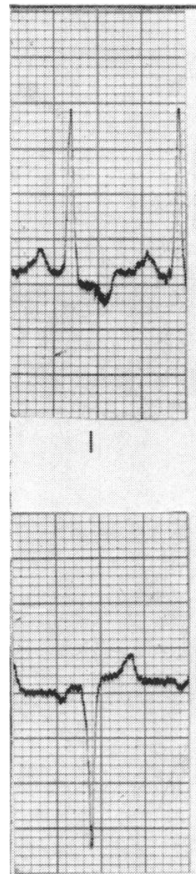

VI

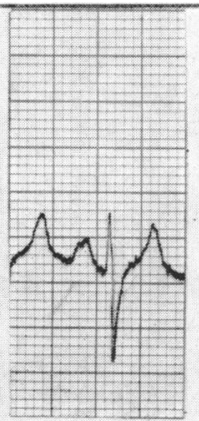

II

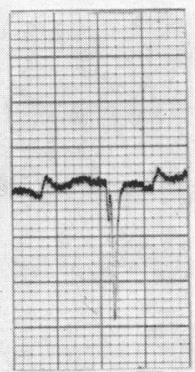

V2

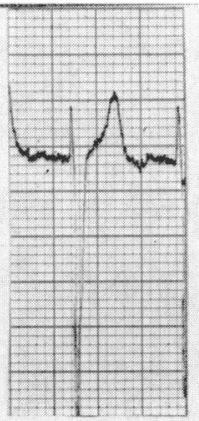

III

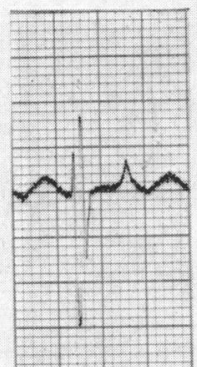

V3



aVR

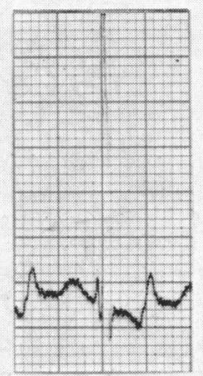

V4

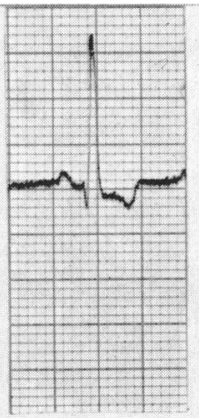

$\mathrm{aVL}$

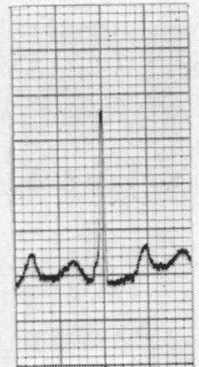

V5

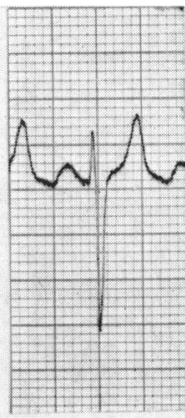

aVF

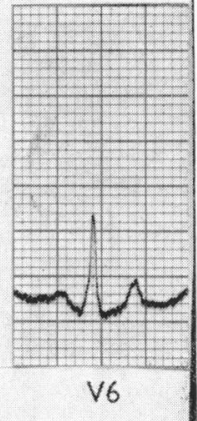

V6

FIG. 4.-Cardiogram of patient P.M., showing left axis deviation and left ventricular preponderance.

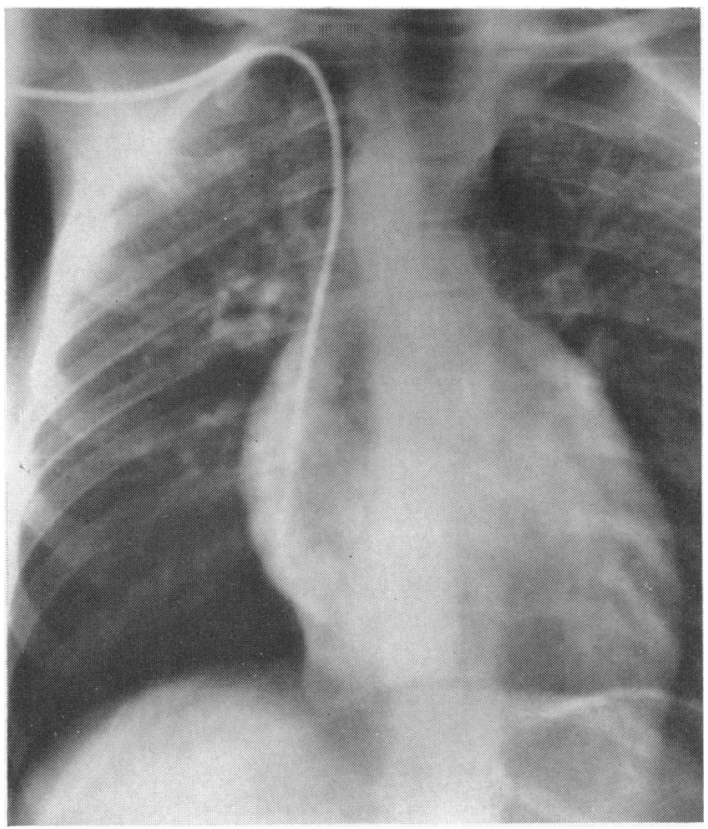

FIG. 5.- Antero-posterior angiocardiogram of patient P.M. Selective right atrial injection shows a straight edge overlying the vertebral column (see text). 
collected at a time when it was generally accepted that this diagnosis could be based upon the combination of cyanotic heart disease and left axis deviation or left ventricular preponderance in the cardiogram. In presenting these cases, Campbell clearly indicated that they were collected because they conformed to these criteria, and several of them have been subsequently proven not to have the anatomical diagnosis of tricuspid atresia: he suggested that the title of his paper would have been more accurate had it been "the tricuspid atresia group".

\section{SUMMARY}

Sixty-five patients with central cyanosis and electrocardiographic evidence of left axis deviation or left ventricular preponderance were studied. The most common causes of these combinations are tricuspid atresia, transposition of the great vessels, and single ventricle. Their order of frequency depends on whether left axis deviation, left ventricular preponderance, or both were used as criteria for assessment.

Tricuspid atresia was found to account for only 40 per cent of our patients having both left axis deviation and left ventricular preponderance in the cardiogram. The occurrence of cases of tricuspid atresia with an electrocardiographic pattern of right ventricular preponderance or right axis deviation is thought to diminish still further the accuracy of electrocardiographic diagnosis of this condition.

I am indebted to Dr. D. C. Deuchar for encouragement and constructive criticism of this paper; to him and Dr. C. G. Baker, P. R. Evans, R. C. Mac Keith, and M. C. Joseph for permission to study their patients at Guy's Hospital. I wish to thank Dr. R. V. Gibson and A. M. Johnson for allowing me to study their patients from Southampton Chest Hospital and Dr. J. D. Dow for performing the angiocardiograms on the patients that I have studied at Guy's Hospital. I am grateful to Miss D. Healy for her assistance during the preparation of this paper.

\section{REFERENCES}

Astley, R. Oldham, J. S., and Parsons, C. (1953). Congenital tricuspid atresia. Brit. Heart J., 15, 287.

Becu, L. M., Swan, H. J. C., DuShane, J. W., and Edwards, J. E. (1955). Ebstein malformation of the left atrioventricular valve in corrected transposition of the great vessels with ventricular septal defect. Proc. Mayo Clin., $30,483$.

Brink, A. J., and Neill, C. A. (1955). The electrocardiogram in congenital heart disease, with special reference to left axis deviation. Circulation, 12, 604.

Campbell, M. (1961). Tricuspid atresia and its prognosis with and without surgical treatment. Brit. Heart J., 23, 699.

Cleland, W. P., Goodwin, J. F., Steiner, R. E., and Zoob, M. (1957). Transposition of the aorta and pulmonary artery with pulmonary stenosis. Amer. Heart J., 54, 10.

Cooley, R. N., Sloan, R. D., Hanlon, C. R., and Bahnson, H. T. (1950). Angiocardiography in congenital heart disease of cyanotic type. II. Observations on tricuspid stenosis or atresia with hypoplasia of the right ventricle. Radiology, 54, 848.

Davignon, A. L., Greenwold, W. E., DuShane, J. W., and Edwards, J. E. (1961). Congenital pulmonary atresia with intact ventricular septum. Clinicopathologic correlation of two anatomic types. Amer. Heart J., $62,591$.

Gardner, D. L., and Cole, L. (1955). Long survival with inferior vena cava draining into left atrium. Brit. Heart J., 17, 93.

Gasul, B. M., Fell, E. H., Mavrelis, W., and Casas, R. (1950). Diagnosis of tricuspid atresia or stenosis in infants. Pediatrics, 6, 862.

- Richmond, J. B., and Krakower, C. A. (1949). A case of tetralogy of Fallot with a patent foramen ovale (pentalogy) showing a marked left ventricular hypertrophy and left axis deviation. J. Pediat., $35,413$.

—-, Weinberg, M., Jr., Luan, L. L., Fell, E. H., Bicoff, J., and Steiger, Z. (1959). Superior vena cava-right main pulmonary artery anastomosis; surgical correction for patients with Ebstein's anomaly and for congenital hypoplastic right ventricle. J. Amer. med. Ass., 171, 1797.

Ingomar, C. J., and Terslev, E. (1962). Complete transposition of the great vessels. Brit. Heart J., 24, 358.

Keith, J. D., Rowe, R. D., and Vlad, P. (1958). Heart Disease in Infancy and Childhood. Macmillan, New York.

Kroop, I. G., and Grishman, A. (1950). The variability of the electrocardiogram in congenital tricuspid atresia. $J$. Pediat., 37, 231.

Meadows, W. R., Bergstrand, I., and Sharp, J. T. (1961). Isolated anomalous connection of a great vein to the left atrium. The syndrome of cyanosis and clubbing, "normal" heart, and left ventricular hypertrophy on electrocardiogram. Circulation, 24, 669

Medd, W. E., Neufeld, H. N., Weidman, W. H., and Edwards, J. E. (1961). Isolated hypoplasia of the right ventricle and tricuspid valve in siblings. Brit. Heart J., 23, 25.

Nadas, A. S. (1957). Pediatric Cardiology. Saunders, Philadelphia. 
Neill, C. A., and Brink, A. J. (1955). Left axis deviation in tricuspid atresia and single ventricle: the electrocardiogram in 36 autopsied cases. Circulation, 12, 612.

Neufeld, H. N., DuShane, J. W., Wood, E. H., Kirklin, J. W., and Edwards, J. E. (1961). Origin of both great vessels from the right ventricle: (1) Without pulmonary stenosis. Circulation, 23, 399.

—, Lucas, R. V., Jr., Lester, R. G., Adams, P., Jr., Anderson, R. C., and Edwards, J. E. (1962). Origin of both great vessels from the right ventricle without pulmonary stenosis. Brit. Heart J., 24, 393.

Noonan, J. A., Nadas, A. S., Rudolph, A. M., and Harris, G. B. C. (1960). Transposition of the great arteries: a correlation of clinical, physiologic and autopsy data. New Engl. J. Med., 263, 592.

Portillo, B., Anselmi, G., Sodi-Pallares, D., and Medrano, G. A. (1959). Importance of the unipolar leads in the diagnosis of dextrocardias, levocardias, dextropositions, and dextrorotations. Amer. Heart J., 57, 396.

Pung, S., Gottstein, W. K., and Hirsch, E. F. (1955). Complete transposition of great vessels in a male aged 18 years. Amer. J. Med., 18, 155.

Sackner, M. A., Robinson, M. J., Jamison, W. L., and Lewis, D. H. (1961). Isolated right ventricular hypoplasia with atrial septal defect or patent foramen ovale. Circulation, 24, 1388.

Scott, G. W. (1955). Congenital tricuspid atresia. Guy's Hosp. Rep., 104, 67.

Shaher, R. M. (1963). The electrocardiogram in single ventricle. Brit. Heart J., $25,465$.

Soloff, L. A. (1949). Congenital aortic atresia: report of the first case with left axis deviation of the electrocardiogram. Amer. Heart J., 37, 123.

Somlyo, A. P., and Halloran, K. H. (1962). Tricuspid atresia: an electrocardiographic study. Amer. Heart J., 63, 171.

Sullivan, J. J., Jr., and Mangiardi, J. L. (1958). Tricuspid atresia with right axis deviation. Amer. Heart J., 55, 450.

Taussig, H. B. (1936). The clinical and pathological findings in congenital malformations of the heart due to defective development of the right ventricle associated with tricuspid atresia or hypoplasia. Bull. Johns Hopk. Hosp., $59,435$.

Tuchman, H., Brown, J. F., Huston, J. H., Weinstein, A. B., Rowe, G. G., and Crumpton, C. W. (1956). Superior vena cava draining into left atrium. Another cause for left ventricular hypertrophy with cyanotic congenital heart disease. Amer. J. Med., 21, 481.

Uhl, H. S. M. (1952). A previously undescribed congenital malformation of the heart: Almost total absence of the myocardium of the right ventricle. Bull. Johns Hopk. Hosp., 91, 197.

Wood, P. (1942). Congenital pulmonary stenosis with left ventricular enlargement associated with atrial septal defect. Brit. Heart J., 4, 11.

(1956). Diseases Of The Heart And Circulation, 2nd ed. Eyre and Spottiswoode, London. 